\title{
A Research on Reading Comprehension Levels of Fifth-Grade Students Who Learned to Read and Write for the First Time with Sound-Based Sentence Method
}

\author{
Muhittin Sağirli ${ }^{1}$, Hatice Kadioğlu Ateş ${ }^{2}$ \\ ${ }^{1}$ Ph.D., Marmara University, Atatürk Faculty of Education, Turkey \\ ${ }^{2}$ Ph.D., Asst. Prof., Istanbul Sabahattin Zaim University, Faculty of Education, Department of Special Education, Gifted \\ and Talented Education, Turkey
}

Correspondence: Muhittin Sağırlı, Marmara University, Atatürk Faculty of Education, Turkey.

Received: December 2, 2015 Accepted: December 4, 2015 Online Published: December 22, 2015

doi:10.11114/jets.v4i3.1230 URL: http://dx.doi.org/10.11114/jets.v4i3.1230

\begin{abstract}
The aim of this study is to determine reading comprehension levels of fifth-grade elementary school students who learned to read and write for the first time with sound-based sentence method. The 2005 program changed the initial literacy learning method. Sentence method was replaced by sound-based sentence method in the initial literacy education. Fifth-grade students comprising the subject of this study may be defined as the first group of students who learned to read and write for the first time with sound-based learning method. The study group comprises a total of 1,000 students attending elementary schools in Üsküdar, Kadıköy, Ataşehir, Ümraniye, Bahçelievler, and Bayrampaşa districts in Istanbul. Both quantitative and qualitative methods were used in the study. The research was conducted during the 2009-2010 academic year. An Achievement Test developed by the researchers was administered to the fifth-grade elementary school students. The test has 15 questions in total. 10 of them are (close-ended) multiple choice questions and 5 of them are open-ended questions. Open-ended questions were administered to 50 students randomly selected from among 1,000 students. Percentage of students' correct answers to the 10 questions in total is $24.41 \%$. Percentage of their wrong answers is $72.68 \%$. Percentage of questions left blank is $0.9 \%$. The ideal is $100 \%$ success in reading comprehension, so $24.41 \%$ may be considered as failure. It may be suggested that students failed to comprehend what they read in the multiple choice questions section. Percentage of students' correct answers to the 5 open-ended questions in total is $43.6 \%$. Percentage of their wrong answers is $28.8 \%$. Percentage of questions left blank is $27.6 \%$. It may be suggested that students failed in the open-ended questions. Students had difficulty expressing themselves. Their written expression skills may be suggested to be insufficient. The reason for this may be that teachers concentrate more on multiple choice tests in their assessments and evaluations, that students do not have developed vocabulary and expression skills, and that they do not have an habit of performing activities of writing essays, stories, letters, diaries, etc.
\end{abstract}

Keywords: sound-based sentence method, initial literacy education, reading comprehension, fifth grade, elementary school

\section{Introduction}

Language is a fundamental and essential component of culture, and also supports culture. Language is the best communicator and supporting system of culture that constitutes the common spirit of a nation formed by a unity of emotions and thoughts (Sağır, 2002). Language can be examined in four primary parts, namely reading, understanding, listening and writing. Reading is comprehending or vocalizing meaning of words with eyes making saccadic movements over lines and thus seeing shapes of words (Öz, 2003). Reading is a mental skill based on comprehending and perceiving printed words. Reading is an action occurring as a result of the mind's perception with the movements of eye and speech organs. Reading is interpretation of written language with verbal expression. Demirel (1999) states, "Reading is an activity of interpretation of printed symbols as a result of joint functioning of cognitive behaviors and psychomotor skills". MOE Turkish language teaching program guidelines (2005) says the following: Reading is a learning area that is the major contributor of mental development.During reading process, what is written is converted into mental concepts, given a meaning and constructed in the brain. Reading is a complex process comprising various 
functions of eye, voice and brain such as seeing, detecting, vocalizing, understanding and constructing in the brain. This process begins with perceiving lines, letters and symbols. Thereafter, attention is focused to understand words and sentences and select information that is of interest and necessary. Selected information undergoes some mental processes such as sorting, classification, inquiry, association, criticism, analysis-synthesis, problem solving and evaluation. Processed information is combined with preliminary information and re-interpreted also using visuals provided in the text. Student's interest, motivation, goal for reading, grammar and reading experiences also affect interpretation.

Areas of activity in Turkish language teaching are described in three categories; comprehension, expression and grammar studies. A mother tongue education includes the teaching categories of comprehension, listening and reading skills. Apart from the family and close environment, children attain a lot of information, skills and attitudes through seeing and hearing on communication tools such as cinema, radio, television, etc. However, most of these are apparently not sufficient to educate a child. Many new information is added everyday to humanity's universe of information. Therefore, people need to establish a more concerted interaction with written culture. On the other hand, people need to build up a cultural wealth starting from the preschool period to make effective use of the means offered by information technologies. The most feasible way to do this is to read and make proper use of written materials. Therefore, reading may be said to have an important function in gaining new learning experiences (Sever, Kaya and Aslan, 2011).

International Association for the Evaluation of Educational. Achievement (IEA). A research was conducted within the framework of the Progress on International Reading Literacy Study (PIRLS) among fourth-grade elementary school students in 35 countries. Within the scope of the research, reading competency of a total of 5,390 students in 154 elementary schools in 62 provinces in Turkey was evaluated. The research concluded that reading skills of the Turkish students were below international standards.

Reading process is also a thinking process. Thinking is a complex process to recognize. There are nine thinking processes used in a reading activity (Cunningham et al., 1995: as cited by Çelenk, 2003): Recalling, connecting, organizing, forming an image, predicting, monitoring, generalizing, applying and evaluating.

Reading and understanding is inter-connected through a cause and effect relationship. The first stage of reading by understanding is reading well. The second stage is comprehending the written material (Demirel and Şahinel, 2006).

Reading is a skill of understanding together with listening. The purpose of reading is to understand what is written. Without understanding, reading does not exist. Reading comprehension involves different skills such as making connections between words, sentences and paragraphs, comprehension, analysis, synthesis, evaluation and interpretation (Coşkun, 2002). Factors effective in reading comprehension can be divided in to two groups:

1. Factors related to the text: Type, narrative organization, language and style (plain or artistic expression; use of metaphors and symbolic elements; readability level; length of sentences...), physical qualities (legibility, length of lines, font size, etc.) of the text

2. Factors related to the reader: Preliminary knowledge of and interest in the text, reading purpose, attention and motivation during reading, and vocabulary of the reader.

While reading comprehension involves finding the meaning of the text, thinking over the meaning, researching its reasons, making inferences and evaluation, it also includes mental activities such as examination, making choices, decision-making, translation, interpretation, postponing, analysis, synthesis and evaluation (Güneş, 2004).

An important factor effective in development of students' reading comprehension skills is collaborative reading. Students may learn best by collaborative reading in social environments where they interact with others who have equal/similar comprehension levels. Collaborative learning can be used in reading comprehension with a partner or in small groups (Epçaçan, 2009).

Reading comprehension strategies can be grouped into four major headings:

1. Pre-reading strategies: Explaining the reading purpose, helping students predict the subject of the text by looking at the title, publication date and author, teaching concepts beforehand through scanning the text, look to the title-examine-look to keywords-re-look to the reading text-prepare story/concept map, pre-teaching vocabulary knowledge, concept maps and story map, selecting reading material with care and allowing students to choose a reading text according to some criteria

2. During-reading strategies: Ensuring fluent and immersive reading, taking into consideration the story map for narrative texts, using drafts and study guides for descriptive reading texts, applying strategic note-taking for descriptive texts, using time charts and flow charts for descriptive texts, preparing complex plans and tables, using visuals for narrative texts. 
3. Post-reading strategies: Making summarization for each type of text, using the question-and-answer relationship.

4. Strategies employed during the entire reading process: Strategic note-taking, SQ4R (survey, question, read, record, recite, review) Mult- pass strategy, reciprocal teaching, what do I know? What do I want to learn? What have I learned? (K-W-L), collaborative strategic reading, concept maps and graphics organizers, ITS reading comprehension strategy, (Coop-Dis-Q), TIOD reading comprehension strategy (POSSE) (Daly In, E. J. Chafouleas, S. Skinner, C. H... 2005:111 as cited by Epçaçan, 2009)

A review of the literature shows that there are several studies on the subject (Şahin, 2011; KuşdemirKayıran and Karabay, 2012; Tok, Tok and Mazı, 2008; Turan and Akpınar, 2008; Kadığlu, 2014; Sağırlı, 2006; Sallabaş, 2007; Sidekli, 2005; Şahin et al., 2005; Güneş, 2005; Güngör and Açıkgöz, 2005; KutlucaCanbulat, 2013; Erginer, 2014; ÜrünKarahan, 2015; Soysal, 2015; Kutlu et al., 2011; Aktaş, 2015; Y1lmaz, 2008; Belet and Yaşar, 2007; Taşdemir, 2010; Işık, 2014; Topuzkanamış and Maltepe, 2010; ÖzderKonedralı and Doğan, 2012; Çiftçi and Temizyürek, 2008; Temizkan and Sallabaş, 2011). Reading comprehension is investigated in these studies under the following headings; Effect of different initial literacy methods on reading comprehension, level of success among elementary school students in all grades in reading comprehension, factors affecting reading comprehension, effect of fast reading techniques on reading comprehension, effect of reading/comprehension strategies on the reading comprehension success, investigation of reading comprehension levels among teacher candidates attending education faculties, investigation of reading strategies, determination of reading comprehension levels according to sound-based sentence method....the 2005 Turkish language teaching program changed the initial literacy learning method. The present study will have a significant place in the literature as it investigates the relationship between reading comprehension skills and different literacy learning methods. Fifth grade is the most appropriate grade level in terms of assessing the reading comprehension skills. The fact that the first group that was applied the sound-based sentence method in the first grade is now attending the fifth grade indicates the importance of conducting the present study during the 2009-2010 academic year. The aim of this study:

1. How is the reading comprehension level of fifth-grade students who learned to read and write for the first time with sound-based sentence method?

\section{Method}

\section{1 Research Design}

Mixed methods research design is a process where quantitative and qualitative methods are used together in collection, analysis and mixing of data (Creswell, 2012). Quantitative research method was used to determine reading comprehension levels of the fifth-grade students. The study group comprised a group of 1,000 students who learned to read and write in the first grade for the first time with sound-based sentence method. A multiple choice test comprised of 10 questions was administered to the 1,000 students. Fifty students selected randomly from among the 1,000 students were asked five open-ended questions. After determining the research problem, literature review was carried out. The researchers reviewed the literature until the end of the reporting process. Validity and reliability work on the data collection tools was carried out by the researchers themselves. Pilot application was carried out in a district elementary school (in Esenler district) that was not included in the study group. Following the pilot application, necessary corrections were made, and the application was commenced. After completion of the statistical processes, data was analyzed and organized. Reporting was also carried out during these processes. The application took two months in total.

\subsection{Study Group}

The study population is the fifth-grade students who learned to read and write for the first time with sound-based sentence method. The study group comprises a total of 1,000 students attending elementary schools in Üsküdar, Kadıköy, Ataşehir, Ümraniye, Bahçelievler, and Bayrampaşa districts in Istanbul. It is important to conduct the study in this year because the first group of students who learned to read and write for the first time with sound-based method is attending fifth grade in this year. Distribution of students in the study group based on gender is as follows: Of the students learning to read and write for the first time with sentence analysis method, 58\% is female (580), and 42\% (420) is male.

\subsection{Data Collection Instruments}

\subsubsection{Validity and Reliability of Achievement Test}

The achievement test created to determine students' reading comprehension levels was developed following revisions made as a result of the preliminary application. The test developed from an anonymous story in accordance with the research objective was developed in live with the views of two Turkish language teachers, three fifth-grade teachers, one elementary school inspector and two experts in the field. The anonymous text entitled "The Mountain with a 
Thousand Mirrors" was administered as the achievement test. Assessment tool prepared in draft was administered to 30 students selected randomly from among fifth-grade students in Esenler district of Istanbul not included among the schools included in the study. As a result of the pre-trial, item analysis for each test item was performed. Questions found inadequate were removed from the assessment tool. One question was revised. As a result of these procedures, Cronbach Alpha coefficient was calculated as 0.672 . As the test was administered by teachers, a directive was attached with the achievement test for test administrators. As a result of the pilot application, the achievement test comprised of 10 multiple choice questions and 5 open-ended questions was prepared in final version. The final test version was administered to the students on consecutive days and in equal periods - one class period Questions answered correctly and incorrectly by each student were identified. Correction form was applied. Final data included the arithmetic mean of the scores of each student in the first and second assessments. Student responses were used to prepare the answer key for the open-ended questions of the achievement test created to determine students' reading comprehension levels. Due care was given to the length of sentences, knowledge of the meaning of words and proper level of knowledge of the meaning of the text for fifth-grade students while preparing the text. Students' vocabulary knowledge was also taken into account.

\subsubsection{Data Collection}

Data obtained in the quantitative part of the study was obtained from a total of 1,000 students attending elementary schools in Üsküdar, Kadıköy, Ataşehir, Ümraniye, Bahçelievler, and Bayrampaşa districts in Istanbul. The qualitative part of the study is the data obtained from the five open-ended questions administered to 50 students selected randomly from among the 1,000 students. The application was conducted during the 2009-2010 academic year. Average time for the application is one class period. Data collection tools were administered by classroom teachers in class environment. The researchers visited the schools where the application was made and met with the teachers and the students. A meeting was held to provide information to the teachers about the application. They discussed the application with the students, visited the classrooms and were present as a guest during the application. The application was led by the classroom teachers. Kendall's W test was applied to determine the consistency among the evaluations made by three different experts on 15 students. The result of the test suggested a statistically significant consistency among the experts (W: $0.88, \mathrm{p}<0.01$ ). 50 students were selected randomly from among those who learned to read and write for the first time with sound-based sentence method. Scoring criterion for the student answers to the open-ended questions is as follows: 2 points for correct and explanatory answer, 1 point for correct and short answer and 0 point for no answer or wrong answer.

\subsubsection{Data Analysis}

In analysis of the data collected at the end of the study to determine reading comprehension levels of students who learned to read and write for the first time with sound-based sentence method in the first grade in elementary school, mean, percentage and frequency points were calculated. Statistics were made using SPSS package program on computer.

\section{Findings and Interpretation}

Findings obtained in the study in accordance with the data collection tools and interpretations are discussed under two headings.

\subsection{Quantitative Findings and Interpretation}

Table 1. Percentage and Frequency Analyses of Answers to the Multiple Choice Section of the Achievement Test of Students Who Learned to Read and Write for the First Time with Sound-Based Sentence Method

\begin{tabular}{ccccccc}
\hline & \multicolumn{2}{c}{ Right Answer } & \multicolumn{2}{c}{ Sound-Based Sentence Method } & \multicolumn{2}{c}{ Not Answered } \\
Questions & $f$ & $\%$ & $f$ & \multicolumn{2}{c}{$\begin{array}{c}\text { Wrong Answer } \\
\%\end{array}$} \\
\hline 1 & 401 & 0,401 & 592 & 0,592 & 7 & 0,007 \\
2 & 159 & 0,159 & 832 & 0,832 & 9 & 0,009 \\
3 & 348 & 0,348 & 643 & 0,643 & 9 & 0,009 \\
5 & 121 & 0,121 & 867 & 0,867 & 12 & 0,012 \\
6 & 199 & 0,199 & 791 & 0,791 & 10 & 0,01 \\
7 & 217 & 0,217 & 779 & 0,779 & 4 & 0,004 \\
8 & 175 & 0,175 & 815 & 0,815 & 10 & 0,01 \\
9 & 79 & 0,079 & 913 & 0,913 & 7 & 0,007 \\
10 & 529 & 0,529 & 465 & 0,465 & 6 & 0,006 \\
\end{tabular}

It is the question item nine in the multiple choice section of the achievement test in which the students who learned to read and write for the first time with sentence method demonstrated the highest success $(0.529 \%)$. The reason for their 
success in this question item might be that the answer to the question is expressly provided in the text.

It is the question item eight in the multiple choice section of the achievement test in which the students who learned to read and write for the first time with sentence method demonstrated the least success $(0.913 \%)$. The reason for their failure in this question item might be that the answer to the question is not expressly provided in the text, that the student is required to use high order thinking skills to reach the answer, and that a logical relationship must be established based on the information provided in the text.

It is the question item ten in the multiple choice section of the achievement test which the students who learned to read and write for the first time with sentence method left blank the most $(0.016 \%)$. The reason for their leaving this question item blank might be that their attention span decreased as it was the last question and that the difficulty level of the question was higher than that of the others.

3.1.1 Mean Calculations for Answers to the Multiple Choice Section of the Achievement Test of Students Who Learned to Read and Write for the First Time with Sound-Based Sentence Method

Percentage of students' correct answers to the 10 multiple choice questions in total is $24.41 \%$. Percentage of their wrong answers is $72.68 \%$. Percentage of questions left blank is $0.9 \%$. The ideal is $100 \%$ success in reading comprehension, so $24.41 \%$ may be considered as failure. It may be suggested that students failed to comprehend what they read in the multiple choice questions section.

\subsection{Qualitative Findings and Interpretation}

Table 2. Percentage and Frequency Analyses of Answers to the Open-Ended Questions Section of the Achievement Test of Students Who Learned to Read and Write for the First Time with Sound-Based Sentence Method

\begin{tabular}{ccccccc}
\hline \multirow{2}{*}{ QUESTIONS } & \multicolumn{2}{c}{ 2 points } & \multicolumn{2}{c}{ 1 point } & \multicolumn{2}{c}{0 point } \\
& $f$ & $\%$ & $f$ & $\%$ & $f$ & $\%$ \\
\hline Q 1 & 32 & 64 & 17 & 34 & 1 & 2 \\
Q 2 & 35 & 70 & 14 & 28 & 1 & 2 \\
Q 3 & 18 & 36 & 26 & 52 & 6 & 12 \\
Q 4 & 6 & 12 & 3 & 6 & 41 & 82 \\
Q 5 & 18 & 36 & 12 & 24 & 20 & 40 \\
\hline
\end{tabular}

It is the question item two in the open-ended questions section of the achievement test in which the students who learned to read and write for the first time with sound-based sentence method demonstrated the highest success $(0.70 \%)$. The reason for their success in this question item might be that the answer to the question is directly provided in the text and that the question can be considered easy for the students.

It is the question item four in the open-ended questions section of the achievement test in which the students who learned to read and write for the first time with sound-based sentence method demonstrated the least success $(6 \%)$. The reason for their failure in this question item might be that the answer to the question is not expressly provided in the text, that the student is required to use high order thinking skills based on the information in the text to reach the answer, and that they are required to have aptitude for analysis, synthesis and evaluation.

It is the question item four in the multiple choice section of the achievement test which the students who learned to read and write for the first time with sound-based sentence method left blank the most (82\%). The reason for their leaving this question item blank might be that this question's level of difficulty is higher than that of the others, that they are required to make an abstract inference from concrete information, and that they are required to be capable of generalization.

3.2.1 Mean Calculations for Answers to the Open-Ended Questions Section of the Achievement Test of Students Who Learned to Read and Write for the First Time with Sound-Based Sentence Method

Percentage of students' correct answers to the five open-ended questions in total is $43.6 \%$. Percentage of their wrong answers is $28.8 \%$. Percentage of questions left blank is $27.6 \%$. It may be suggested that students failed in the open-ended questions.

Students had difficulty expressing themselves. Their written expression skills may be suggested to be insufficient. The reason for this may be that teachers concentrate more on multiple choice tests in their assessments and evaluations, that students do not have developed vocabulary and expression skills, and that they do not have an habit of performing activities of writing essays, stories, letters, diaries, etc.

\section{Discussion, Conclusion and Recommendations}

The results of the present study conducted to determine reading comprehension levels of students who learned to read and write for the first time in first grade with sound-based sentence method are as follows: 
Percentage of students' correct answers to the 10 multiple choice questions in total is $24.41 \%$. Percentage of their wrong answers is $72.68 \%$. Percentage of questions left blank is $0.9 \%$. The ideal is $100 \%$ success in reading comprehension, so $24.41 \%$ may be considered as failure. It may be suggested that students failed to comprehend what they read in the multiple choice questions section.

Percentage of students' correct answers to the five open-ended questions in total is $43.6 \%$. Percentage of their wrong answers is $28.8 \%$. Percentage of questions left blank is $27.6 \%$. It may be suggested that students failed in the open-ended questions. Students had difficulty expressing themselves. Their written expression skills may be suggested to be insufficient. The reason for this may be that teachers concentrate more on multiple choice tests in their assessments and evaluations, that students do not have developed vocabulary and expression skills, and that they do not have habit of performing activities of writing essays, stories, letters, diaries, etc.

It may be suggested that students who learned to read and write for the first time with sound-based sentence method failed in reading comprehension. Also, students are seen to be more successful in open-ended questions than in multiple choice questions. The following researches are seen in the literature that has overlapping findings.

According to Şahin et al. (2005), first grade teachers find sound-based sentence method more favorable than the sentence method in reading comprehension. Güneş (2005) suggested that, according to the results of the application in pilot schools, attention and comprehension levels of students who learned to read and write for the first time with sound-based sentence method increased in comparison to the past. Sağırlı (2006) found that, according to the teacher views, sound-based sentence method was better qualified for qualitative literacy learning (78\%). Teachers who participated in the study stated that memorization was prevented and that more meaningful learning was achieved.

The findings of the following studies in the literature do not match those of the present study.

TemizkanveSallabaş (2011) compared multiple choice tests and open-ended written tests in their evaluation of the reading comprehension skills of elementary school students. At the end of the study, the students proved to be more successful in multiple choice questions than in open-ended questions in terms of reading comprehension level. The research conducted by Turan ve Akpinar (2008) on teachers' preferences of sound-based sentence method and sentence analysis method in initial literacy education suggested that, according to the teachers, sentence analysis method was more effective in reading comprehension and high speed reading. According to Kadıoğlu (2012), teachers find initial literacy teaching with sentence analysis method more positive than initial literacy teaching with sound-based sentence method in high speed reading and reading comprehension.

According to the findings of the present research, students learning to read and write for the first time with sentence analysis method can be considered successful in reading comprehension. Another study with similar finding is as follows: Tok, Tok and Mazi (2008) suggested that, according to the teachers, sentence analysis method achieved more meaningful and faster reading in initial literacy education.

The method may inevitably lead to unfavorable results if it does not match students' characteristics and is not used effectively by the teacher and if the prepared course material does not reflect the essence of the method (KutlucaCanbulat, 2013). The reasons such as that the the method was applied for the first time in that year, that the teachers were not sufficiently informed, that textbooks, supplies, guide books were not distributed to teachers or students in a timely and complete manner, and that there wasn't many documents available about the method (printed material with cursive handwriting - story books, stories, beginners' book sets) and failures in the method's applications may have led to student failure. According to KutlucaCanbulat (2013), teachers were not trained in teaching with sound-based sentence method. Therefore, they are not competent in the application.

Children must be given children books and magazines as well as alphabet and reading books starting from the first day of school to promote reading during their spare times. Color illustrations, short texts, free writing styles, various text types, their difficulty levels and different topics being addressed in the magazines are elements that can attract interest of anyone of any age. Reading material must be easily accessible and offered in appropriate forms to promote reading among children. Every elementary school must have the appropriate equipment to allow children to read. In other words, there must be at least one school library and class libraries and reading corners. A teacher's duty in Turkish education is to facilitate learning. For this, a teacher observes his students with attention, and guide and help them. A teacher should not be someone who only asks questions, but also who teaches the students how to critically approach what is read or listened to, and allows them to ask questions about, reason, compare and evaluate the text. A teacher must be the guide who prepares an appropriate environment for students to produce ideas and describe their feelings (Sever, Kaya and Aslan, 2011). Not only Turkish teachers, but also teachers teaching other subjects must promote reading comprehension skills. Teachers must help students comprehend what they read in all expression and skill classes in every level of education using strategies developing reading comprehension skills (pre-, during- and post-reading strategies). Having students summarize what they read, develop questions as homework, develop individual questions from the text, and 
work on the main theme are among the methods that can be used by teachers. The most important method for assessing reading comprehension is asking questions. Frequent use of questioning skills and making students use these skills can help students develop such skills. The future research may assess the effect of sound-based sentence method on comprehension level as this method is now used in initial literacy education. Comprehension levels of students who learned to read and write for the first time with different methods may be assessed to find their effect on comprehension level. Factors affecting reading comprehension may be determined based on the views of classroom teachers and Turkish language teachers. Factors affecting reading comprehension (number of books being read, frequency of newspaper reading, parents' education level, Turkish language course achievement...) may be the focus of other research. Due care must be paid to include all types of question types in tests chosen as assessment tools. It is proper to use both multiple choice questions, open-ended questions and fill-in-the-blank questions. There are various ways of comprehending what is read. Only one assessment tool may be insufficient. Some of the methods that may be used are to allow discussions, use projects and performance assignments, make students scribe, ask questions, have them make presentations and prepare books, make group studies, etc... If open-ended questions are being asked, the answer key must be prepared as such to include a wide range of possible answers. An answer key containing multiple probabilities will contribute to the validity and reliability of the assessment. In order to eliminate the possibility of having coincidental correct answers in multiple choice questions at levels requiring high level logical operations, the option of four incorrect answers canceling out one correct answer may be used. Thus, the difference between students who knows and who doesn't know can be clearly identified. One negative aspect of this type of assessment is that multiple choice questions do not assess creativity and essay skills. One of the disadvantages of multiple choice questions is that it has students mark an answer without using high order skills. Considering the limitations of multiple choice questions and open-ended questions, it is important to use both together in terms of assessment of reading comprehension. (Sağırl1, 2016) Teachers can use reading comprehension strategy in development of students who fail in reading comprehension. Strategies used by students in the classrooms must be determined and students failing in the use of strategy must be educated (Ekiz, Erdoğan and Uzuner, 2012).

It is beyond doubt that there are students having difficulty understanding what they read in the elementary education. Bearing in mind that reading comprehension is not an assignment or a tool to get good grades, but a necessity and duty, students must be motivated to make inferences from what they read during their free book reading times. Students may be asked to describe what they understand from stories they read to their parents and siblings in their daily lives. They may be advised to read and comment on newspapers to their grandparents. They may be recommended to keep a summary notebook to write down what they understand from what they read and have it checked by their teachers. They must be encouraged to attain awareness of using all means to develop their comprehension skills with such activities not only within, but also without school (Sağırlı, 2016).

\section{References}

Aktaş, N. (2015). Okuma Öncesi Strateji Öğretiminin 4. Sinı Öğrencilerinin Ekrandan Okuduğunu Anlama Düzeyine Etkisi, Yayımlanmamış Yüksek Lisans Tezi. Gazi Üniversitesi Eğitim Bilimleri Enstitüsü, Ankara.

Akyol, H., Yıldııı, K., Ateş, S., Çetinkaya, Ç., \& Rasinski, T. V. (2014). Okumayı Değerlendirme. Pegema Yayıncılık, Ankara.

Aytaş, G. (2005). Okuma Eğitimi, Türk Eğitim Bilimleri Dergisi, C. 3., S. 4, ss: 461-470.

Belet, D., \& Yaşar, Ş. (2007). "Öğrenme Stratejilerinin Okuduğunu Anlama ve Yazma Becerileri ile Türkçe Dersine İlişkin Tutumlara Etkisi” Eğitimde Kuram ve Uygulama, 3(1), 69-86.

Coşkun, E. (2002). Okumanın Hayatımızdaki Yeri ve Okuma Sürecinin Oluşumu, Türklük Bilimi Araştırmaları, 11, 231-244.

Creswell, J. W. (2012). EducationalResearch, PearsonEducation, Inc., Boston, MA.

Çelenk, S. (2003). İlkokuma Yazma Programı ve Öğretimi. Anı Yayıncılık. Ankara.

Çelenk, S. (2007). Çağdaş Öğretim Yaklaşımlarının Işığında İlk okuma ve Yazma Öğretimi. Editör: Ayla Oktay, Özgül Polat Unutkan. Alan Öğretimi. Morpa: İstanbul.

Çiftçi, Ö., \& Temizyürek, F. (2008). İlköğretim 5. Sınıf Öğrencilerinin Okuduğunu Anlama Becerilerinin Ölçülmesi. Mustafa Kemal Üniversitesi Sosyal Bilimler Enstitüsü Dergisi, 5(9), 109-129.

Demirel, Ö. (1999). Türkçe Programı ve Öğretimi. Kardeş Yayınevi. Ankara.

Demirel, Ö. (2002). Plandan Değerlendirmeye Öğretme Sanatı. Ankara: PegemA yayınc1lık.

Demirel, Ö., \& Şahinel, M. (2006). Türkçe Ve Sinıf Öğretmenleri Iç̧in Türkçe Öğretimi. Ankara: Pegema Yayınları. 
Ekiz, D., Erdoğan, T., \& Uzuner, F. G. (2012). Aksiyon Araştırması Aracılığıyla Okuduğunu Anlama Becerisinin Geliştirilmesi. The Journal of Academic Social Science Studies, 5(7), 303-328.

Epçaçan, C. (2009). Okuduğunu Anlama Stratejiklerine Genel Bir Bakış. Uluslararası Sosyal Araştırmalar Dergisi, 2(6), 207-223.

Güleryüz, H. (2000). Programlanmış Illk Okuma Yazma Öğretimi Kuram ve Uygulamaları. Ankara: Pegema Yayıncılık.

Güneş, F. (2004). Okuma Yazma Öğretimi ve Beyin Teknolojisi. Ankara: Ocak Yayınları.

Güneş, F. (2005). Türkçe Öğretim Programının Yenilikleri, Artı Eğitim Dergisi, (2).

Güngör, A., \& Açıkgöz, K. (2005). İşbirlikçi Öğrenme ve Geleneksel Öğretimin Okuduğunu Anlama Üzerinde Etkileri ve Cinsiyet ile İlişkileri. Kuram ve Uygulamada Ĕ̈itim Yönetimi Dergisi, (4).

Işık, A. E. (2014). 60-66 Aylık İken Illkokula Başlayan Öğrencilerin Okuma Yazma Beceri Gelişimlerinin İncelenmesi, Yayımlanmamış Yüksek Lisans Tezi. Uşak Üniversitesi Sosyal Bilimler Enstitüsü: Uşak.

Kadıŏlu, H. (2012). İlköğretim Birinci Sınıf Öğrencilerinin Bitişik Eğik Yazma Becerisi, Hızı ve Tutumlarının Incelenmesi. Şenyıldız:İstanbul.

Kayalan, M. (2000). Etkili ve Hızlı Okuma Sanatı. İstanbul.

Kuşdemir, K. B., \& Karabay, A. (2012). A Study On Reading Comprehension Skills of Primary School 5th Grade Students-Learning Basic Reading and Writing Skills Through Phonics-BasedSentence Method Or Decoding Method, Kuram ve Uygulamada Eğitim Bilimleri, 12(2), 2854-2860.

Kutlu, Ö., Yıldırım, Ö., Bilican, S., \& Kumandaş, H. (2011). İlköğretim 5. Sınıf Öğrencilerinin Okuduğunu Anlamada Başarılı Olup Olmama Durumlarının Kestirilmesinde Etkili Olan Değişkenlerin İncelenmesi. Eüitimde ve Psikolojide Ölçme ve Değerlendirme Dergisi, 2(1), 132-139.

Kutluca, C. A. (2013). Okula Destek Eğitiminin Etkililiği. Yayımlanmamış Yüksek Lisans Tezi. Abant İzzet Baysal Üniversitesi Eğitim Bilimleri Enstitüsü, Bolu.

MEB Talim Terbiye Kurulu Başkanlığı. (2005). İlköğretim Türkçe Dersi Öğretim Programı ve Kılavuzu. Ankara: MEB Basımevi.

Öz, M. F. (2003). Uygulamalı Türkçe Öğretimi. Anı Yayınları, Ankara.

Özdemir, E. (1983). Okuma Sanatı. İstanbul: Varlık yayınları

Özder, H., Konedralı, G., \& Doğan, H. (2012). İlkokul Beşinci Sınıf Öğrencilerinin Okuduğunu Anlama Becerilerinin Değerlendirilmesi. Uluslar arası Eğitim Programları ve Öğretimi Çalışmaları Dergisi, $1,3$.

Sağır, M. (2002). Türkçe Dil Bilgisi Öğretimi. Ankara: Nobel Yayın Dağıtım

Sağırlı, M. (2006). Ses Temelli Cümle Yönteminin İlk Okuma-Yazma Öğretimi Süreç ve Etkinlikler Üzerindeki Başarısının Uygulama Öğretmenleri Tarafindan Değerlendirilmesi, Ulusal Sınıf Öğretmenliği Kongresi, Gazi Üniversitesi, Ankara: Kök Yayıncılık, Cilt:2

Sağırlı, M. (2016). Analysis of Reading Comprehension Levels of Fifth Grade Students Who Learned to Read and Write with the Sentence Method. Journal of Education and Training Studies, 4(2). http://dx.doi.org/10.11114/jets.v4i2.1122

Sallabaş, M., E. (2007). İlköğretim Besinci Sinıf Öğrencilerinin Kendini Yazılı Olarak Ífade Etme Kazanımlarına Ulaşma Düzeyi. Yayımlanmamış Yüksek Lisans Tezi. Gazi Üniversitesi Eğitim Bilimleri Enstitüsü

Sever, S., Kaya, Z., \& Aslan, C. (2011). Etkinliklerle Türkçe Öğretimi. Tudem: İzmir.

Sidekli, S. (2005). Illköğretim Besinci Sinı Öğrencilerinin Öğretici ve Öyküleyici Metinlere Göre Okuduğunu Anlama Becerilerinin Sinanması. Yayımlanmamış Yüksek Lisans Tezi. Gazi Üniversitesi Eğitim Bilimleri Enstitüsü

Soysal, T. (2015). Hızlı Okuma Tekniklerinin Beşinci Sınıf Öğrencilerinin Okuma Hızlarına Ve Anlama Düzeylerine Etkisi. Yayımlanmamış Yüksek Lisans Tezi. Abant İzzet Baysal Üniversitesi Eğitim Bilimleri Enstitüsü, Bolu.

Şahin, A. (2011). Farklı Yöntemlerle Okuma Yazma Öğrenmiş 5. Sınıf Öğrencilerinin Okuduğunu Anlama Erişileriyle Okuma Hızlarının Karşılaştırılması. Hacettepe Üniversitesi Eğitim Fakültesi Dergisi, 41, 423-433.

Şahin, İ., İnci, S., Turan, H., \& Apak, Ö. (2006). İlkokuma Öğretiminde Ses Temelli Cümle Yöntemiyle Çözümleme Yönteminin Karşılaştırılması. Milli Ĕgitim, 171, 109-129.

Taşdemir, M. (2010). Ders Kitaplarının Kullanımında Anlama Stratejilerinin Kullanımı ile Başarı Arasındaki İlişki Üzerine Bir Durum Çalışması. Türk Eğitim Bilimleri Dergisi, 8(4), 913-947. 
Tazebay, A. (1997). Illkokul Öğrencilerinin Okuma Becerilerinin Okuduğunu Anlamaya Etkisi. MEB, Ankara.

Temizkan, M., \& Sallabaş, M. E. (2011). Okuduğunu Anlama Becerisinin Değerlendirilmesinde Çoktan Seçmeli Testlerle Açık Uçlu Yazılı Yoklamaların Karşıllaştırılması, Dumlupınar Sosyal Bilimler Dergisi, 30, 207-220.

Tok, Ş., Tok. T. N., \& Mazı, A. (2008). İlkokuma Yazma Öğretiminde Çözümleme ve Ses Temelli Cümle Yöntemlerinin Değerlendirilmesi. Kuram ve Uygulamada Ĕgitim Yönetimi Dergisi, 53, 123-144.

Topuzkanamış, E., \& Maltepe, S. (2010). Öğretmen Adaylarının Okuduğunu Anlama Ve Okuma Stratejilerini Kullanma Düzeyleri, TÜBAR-XXVII, 655-677.

Turan, M., \& Akpınar, B. (2008). İlköğretim Türkçe Dersi İlk Okuma Yazma Öğretiminde Kullanılan Ses Temelli Cümle ve Bitişik Eğik Yazı Yöntemlerinin Değerlendirilmesi. Fırat Üniversitesi Sosyal Bilimler Dergisi. Cilt: 18, sayı:1 sayfa:121-138, Elazığ.

Ünal, E., \& Köksal, K. (2007). Okuduğunu Anlama ve Sorular. Üniversite ve Toplum: Bilim, Eğitim ve Düşünce Dergisi. Cilt: 7, Say1:4 , Aralık 2007. http://www.universite-toplum.org

Ürün, K. B. (2015). 5. ve 6. Sinı Ö̆grencilerinin Okumaya Karşı Tutum Ve Motivasyonlarının Okuduğunu Anlama Becerileri İle İlişkisi. Yayımlanmamış Yüksek Lisans Tezi. Atatürk Üniversitesi Eğitim Bilimleri Enstitüsü, Erzurum.

Yılmaz, M. (2008). Türkçede Okuduğunu Anlama Becerilerini Geliştirme Yolları. Mustafa Kemal Üniversitesi Sosyal Bilimler Enstitüsü Dergisi, Cilt:5 Sayı:9, 131-139.

Yılmaz, M., \& Ağırtaş, M. N. (2009). İlk Okuma Yazma Öğretiminde Ses Temelli Cümle Yönteminin Öğretmen Görüşlerine Göre Değerlendirilmesi. Hatay Il Örneği. Mustafa Kemal Üniversitesi Sosyal Bilimler Enstitüsü Dergisi, 6(12), 164-175.

\section{$(\infty)$ EY}

This work is licensed under a Creative Commons Attribution 3.0 License. 